\title{
Фоброоптичната епифарингоскопия в подкрепа на диагнозата обструктивна сънна апнея при деца
}

\author{
Д. Николов, Н. Криворов, И. Йовчев \\ Катедра УНГ-болести, Медицински университет - Пловдив
}

\section{Въведение}

Една от най-честите причини за консултация с педиатър или оториноларинголог в детската възраст е нарушеното носно дишане, особено демонстративно по време на сън. То може да бъде преходно в резултат на възпалителни или алергични заболявания на носната лигавица, но може да бъде и компонент на синдрома на обструктивна сънна апнея (ОСА), състояние с дълготрайни последствия за детския организъм. Честотата на нарушение в дишането по време на сън, включително хабитуално хъркане, варира в широки граници - 3.2-12\%, а случаите на истинска ОСА се съобщават в $0.7-10.3 \%$ [1-3].

Последствията от ненавременната диагноза на ОСА са значителни и могат да варират от дневна сънливост и промени в поведението до пулмонална хипертензия и кор пулмонале, изоставане в развитието [4].

Най-честата причина за ОСА се явява хипертрофията на аденоидната вегетация и небните тонзили, а тяхното хирургично премахване за повлияване на OCA се налага като по-честата индикация от хроничните тонзилити и аденоидити [5]. Същевременно диагностиката на OCA е едно от предизвикателствата пред съвременните педиатри и оториноларинголози поради трудностите при работа с деца и липсата на лесен метод за регистриране на нарушенията в съня и промените на физиологичните показатели вследствие на ОСА. Най-често използваните методи са все още анамнезата и прегледът, като шумното хъркане, наблюдавана от родителите апнея, често разбуждане нощем и хроничното дишане през устата, наред с хипертрофия на небните тонзили и най-вече аденоидна вегетация са признаци, характерно свързани с ОСА. 
Съвременните методи за диагностика на OCA предлагат използването на полисомнографско изследване като златен стандарт за доказване на диагнозата, подобно на възрастните [6]. Същевременно данните от научни публикации по въпроса не дават еднозначно предимство на този метод [7-8], значението на добрата анамнеза и обективен преглед продължават да имат важно значение за поведението при съмнение за ОСА с акцент върху опасността от висок процент хипердиагностика. Наличието на аденоидна вегетация като основна причина за ОСА налага необходимостта от прецизно диагностициране на степента на разрастване на последната. Изключително удачен метод за верификация на аденоидната хипертрофия и отношението ѝ към съседни анатомични структури, и най-вече към дихателните пътища, е флексибилната трансназална ендоскопия. Съвременните фиброскопи имат изключително фини флексибилни накрайници, които много добре се толерират от децата в различна възраст [9].

\section{Методи и материали}

В рамките на 12 месеца в Клиниката по оториноларингология към МУ - Пловдив подложихме на трансназална фиброназоскопия (ФНС) 43 деца на възраст между 2 години и 11 месеца и 7 години и 3 месеца, насочени кък клиниката за оперативно лечение на ОСА. От тях 20 (46.5\%) бяха момичета, а 43 (53.5\%) - момчета, без други значими системни заболявания и анамнеза за алергични реакции. За аденотомия бяха насочени 35 (81.4\%) от всички случаи, а при 8 (18.6\%) се извърши аденотонзилектомия. Извършването на ФНС се извърши след получаване на съгласие от всяко дете и подписана от родител форма за информирано съгласие, в съответствие с установения ред в клиниката. Дадена бе възможност на децата да се уверят сами, че светлината на фиброскопската апаратура не предизвиква болеви усещания, като манипулацията бе осъществена допълнително под местна анестезия с лидокаин 1\% в присъствието на анестезиолог. Самата ФНС бе осъществена с aпарат Olympus с диаметьр на флексибилната част 2.2 мм и работен канал 1 мм, като всяка манипулация бе заснета на видеоносител. Процедурата бе понесена добре от всички деца без изключение, което подсигури възможността за осъществяване на същата при контролен преглед впоследствие.

По време на ФНС се установи хипертрофия на небната тонзила от 3-та степен при 40 от децата в потвърждение на диагнозата ОСА, при другите 3 степента на хипертрофия бе гранична между 2-ра и 3-та. Всички случаи бяха подложени на оперативна намеса, като фиброскопската апаратура бе използвана и за контрол на хирургичната намеса интраоперативно. Огледът на назофаринкса след приключването на аденотомията не увеличи времето под обща наркоза и не доведе до промени в поведението на анестезиологичния екип. Същевременно информацията, получена от това изследване, наложи отстраняването на скрити за оператора вегетации около тубарните отверстия в $7(16.2 \%)$ от случаите, което не бе сыпроводено от усложнение.

Постоперативно не се наблюдаваха ранни усложнения, а контролните прегледи се извършваха на 7-я ден и 1-я месец от оперативната намеса. ФНС бе осъществена при всички случаи и отново бе толерирана добре от децата.

От всички 43 деца подобрение в носното дишане на 7-я ден потвърдиха 27 (62.7\%) родители, останалите 16 (37.3\%) не можеха да бъдат категорични за съществена промяна в състоянието. При контролния преглед след един месец обаче 39 (90.7\%) съобщават за значително подобрение в съня, подобрен апетит и видимо по-добро физическо състояние на децата, родителите на останалите 4 деца съобщават за резидуално хъркане нощем. При всички случаи аденоидните вегетации бяха премахнати напълно, верифицирано от извършената $Ф Н С$.

\section{Дискусия}

OCA е често състояние в детската възраст, чието диагностициране и отдиференциране от хабитуалното хъркане е трудно и стандартите за диагноза при възрастни не могат да бъдат пренесени автоматично при децата. Наред с високоспециализираните изследвания като полисомнография и езофагеална манометрия важна роля играят и анамнезата и физикалното изследване, като внимание трябва да се обърне на високия риск от фалшиво положителни данни за ОСА и ненужно извършени аденотомии. Възможността за използване на допълнителни методи за диагностициране на свързаните с ОСА състояния като аденоидна и тонзиларна хипертрофия могат в значителна степен да подобрят терапевтичните подходи. Контрольт на повлияването на ОСА може да се осъществи и с помощта на различни от полисомнографията методи в случаите, в които последната е затруднена или няма възможност за осъществяването ѝ, като съществува необходимост от стандартизиран подход. 


\section{Заключение}

Флексибилната назофарингоскопия, извършена със съвременна апаратура с минимален диаметьр на гъвкавия накрайник, дава изключително достоверна информация за разрастването на аденоидната вегетация като основна причина за ОСА. Тя може да бъде приложена лесно и ефективно с висок процент сьгласие от обектите на изследването дори и в амбулаторни условия и се понася добре.

\section{Литература:}

1. Schechter MS: Technical report: diagnosis and management of childhood obstructive sleep apnea syndrome. Pediatrics 2002; 109: e69

2. Brunetti L, Rana S, Lospalluti ML, Pietrafesa A, Francavilla R, Fanelli M, Armenio L: Prevalence of obstructive sleep apnea syndrome in a cohort of 1,207 children of southern Italy. Chest 2001; 120: 1930-5

3. American Thoracic Society: Standards and indications for cardiopulmonary sleep studies in children. Am J Respir Crit Care Med 1996; 153: $866-878$

4. Richards W, Ferdman RM: Prolonged morbidity due to delays in the diagnosis and treatment of obstructive sleep apnea in children. Clin Pediatr (Phila) 2000; 39: 103-8

5. Messner AH: Treating pediatric patients with obstructive sleep disorders: an update. Otolaryngol Clin North Am 2003; 36: 519-30

6. American Thoracic Society. Standards and indications for cardiopulmonary sleep studies in children. Am J Respir Crit Care Med 1996; 153: 866-878.
Рискът от подобна манипулация е минимален в ръцете на опитен и обучен екип и се препоръчва както предоперативно за намаляване на ненужните хирургични манипулации, така и по време на оперативната намеса за контрол на крайния резултат и намаляване на случаите на рецидив. Нейната роля е удачна и при постоперативния контрол на симптоматиката и дава възможност за обективно проследяване на клиничната симптоматика.
7. Brietzke SE, Katz ES, Roberson DW. Can history and physical examination reliably diagnose pediatric obstructive sleep apnea/hypopnea syndrome? A systematic review of the literature [review]. Otolaryngol Head Neck Surg 2004; 131: 827-832.

8. Goldstein NA, Pugazhendhi V, Rao SM, et al. Clinical assessment of pediatric obstructive sleep apnea. Pediatrics 2004; 114: 33-43.

9. Sensitivity and specificity of nasal flexible fiberoptic endoscopy in the diagnosis of adenoid hypertrophy in children. Christine Aparecida Kindermann, Renato Roithmann, José Faibes Lubianca Neto. International Journal of Pediatric Otorhinolaryngology, January, 2008 (Vol. 72, Issue 1, Pages 63-67)

Настоящата публикачия е част от научен проект ДОО2.349/29.12.08 2. „Интегриран научно-изследователски център по детско здраве“, осъществяван с финансовата подкрепа на Фонд „Научни изследвания“ към МОН. 